\title{
Risks Associated with Agricultural Product Carrying in Nigeria: Implication for Policy on Occupational Safety and Social Well-being
}

\author{
Meludu Nkiru T. \\ Department of Agricultural Extension and Rural Development, University of Ibadan, Ibadan, \\ Oyo State, Nigeria \\ Telephone: +8023250457; E-mail: nkiru_m@yahoo.com
}

KEYWORDS Health Problem. Labourers. Reduced Capability. Psychology. Health Management

\begin{abstract}
Under development and poverty has resulted in various health risks in our labour force, especially with getting agricultural products to the final consumer. The research was undertaken to determine the occupational health problems of agricultural product carriers in the selected markets of Ibadan North Local Government Area of Oyo State. Simple random sampling method was used to select 120 male and female respondents for the research project. The result revealed that a high proportion of the respondents $(31 \%)$ had primary school education. Thirty eight percent of them have been on the job for over 16 years. The result revealed that their major source of income is agricultural products carrying. Also the result revealed that the daily income of the respondents is above $\mathrm{A} 200.00$ per day. Chi-square analysis indicated that there is significant association between $\operatorname{sex}\left(\chi^{2}=1.118, \mathrm{p}<0.05\right)$, marital status $\left(\chi^{2}=10.740, \mathrm{p}<0.05\right)$ and their involvement in such activities. However, there is no significant association between faith based, educational status and their income generating activity. The study also revealed that there is significant correlation between constraints faced $(\mathrm{r}=0.736, \mathrm{p}<.000)$; activity $(\mathrm{r}=0.832<0.034)$ and health problems (data). The implications of the health problems, especially for women, are that it affects their reproductive and productive capacity, causing serious pains on their bodies, which invariably affect their food security status. Provision of trolley and other load lifting gadgets will help to enhance their income generation through load carrying.
\end{abstract}

\section{INTRODUCTION}

Agricultural product carriers can be regarded as belonging to the agricultural labour force. They ensure the transportation of farm produce from the farm to the farm gate and from the farm gate to the marketing points. They also help marketers to convey their agricultural products purchased within the market to a desired location. Most agricultural products are often transported through the use of shoulder, head, wheelbarrow, baskets and carts. It has been noticed that people ranging from men, women and even young children are involved in carrying agricultural products in different markets. These agricultural product carriers can often be characterized as illiterate, less privileged people or people migrating from rural areas in search of greener pastures. The aspirations of these agricultural product carriers were initially high before migrating to the urban areas. Most times, the situation was different from what they often expected, therefore in order to survive in their new environment; they engaged themselves in a lot of activities for their survival such as carrying both agricultural and non-agricultural products.

\section{Health Implications for Agricultural Product Carriers}

The right to health is the most basic need of man and is a fundamental objective of social and economic development. The constitution of the World Health Organization (WHO) asserts that: "The enjoyment of the highest attainable standard of health is one of the fundamental rights of every human being without distinction of race, faith based, political belief and economic/ social conditions" (WHO, 2002). This means that every human being has the right to live in an environment with minimum health risk, and to have access to health services that can alleviate their suffering treat diseases and help maintain and promote good health throughout the individual's life. Many product carriers are often being denied this basic human right. Anyanwu (1993), confirmed that significant proportion of Nigerians do not enjoy a level of health that will enable them to achieve socially and economically productive lives. The persistent health problems, adverse effects of the activities of the agricultural product carriers, high morbidity and mortality rates have greatly impaired agricultural product carriers' potentials for optimum livelihood. The 
state of health of a person is directly related to his efficiency in his field of work, as health is important to the body and economic development. Agriculture is often one of the most hazardous sectors in both the developing and industrial countries. It is ranked as one of the three most hazardous industries together with mining and construction (National Safety Council, 2004). According to ILO estimates for 1997, out of a total of 330,000 fatal work accidents worldwide, there were some 170,000 casualties among agricultural workers (National Safety Council, 2004).

\section{Difficulty in Transportation of Agricultural Products}

Production, trade and daily life require the movement of goods and service. Different transport technologies exist, employing human energy, animal power or the use of motors. They range from basic walking and carrying to largescale motorized transport, including motorcars, large trucks and buses, trains, aircraft and ships (Folasola, 2005). Between these extremes, there is a wide range of intermediate means of transport that can increase transport capacity and reduce human drudgery without the high costs associated with large motor vehicles. Options include single-wheel technologies (e.g. wheelbarrows), two-wheel handcarts, bicycles and tricycles, motorcycles, animal-powered transport and low cost boats. The many transport options available have different ranges, capacities and operating costs. These over lap and provide a continuum of complementary transport options, each with advantages and disadvantages. They vary in purchase price, payload, complexity and their requirement for work, animals, mechanics, foreign exchange and road quality. The development of transport systems in sub-Saharan Africa has often been given high priority by national governments and by development agencies. Government ministries concerned with transport and regional development, with the support of donor agencies, have concentrated on transport infrastructure including roads, railways, ports and airports. Since 1985, about $15-20$ percent of World Bank loans have been for transport investments (roads, ports and railways) with US $\$ 40$ billion in loans/credits, of which about US\$ 2.5 billion (about 6\%) has been specifically for rural transport (Bamberger and Lebo, 1999). However, nearly all these fundings had been dedicated to infrastructure and large-scale transport systems. Transport planners have often paid little attention to intermediate means of transport. The bias towards infrastructure and large-scale transport still exists in national governments and donor agencies, and is reflected in terms of budgets, personnel and professional training. The focus is on large scale transport system at the neglect of the small-scale transport systems and means of carrying agricultural products.

In the 1960s and 1970s, the first two postindependence decades for most sub-Saharan countries, national governments and donor agencies put emphasis on expanding road networks with little regards to the problems of sustainability. However, it became increasingly obvious that inadequate rural transport and poor accessibility remained serious constraints to rural life and development. The international labour organization (ILO) in collaboration with the Intermediate Technology Development Group (ITDG) commissioned a number of village-based transport studies in Africa. These studies proved influential by highlighting the importance and magnitude of human-powered transport studies in Africa (Howe and Zille, 1988; Barwell and Malmberg Calvo, 1989; Airey and Barwell, 1991; Dawson and Barwell, 1993). It became clear that large-scale investment in infrastructure was having very little impact on family and village level transportation problems. This shows that, there has been a serious problem in small-scale transportation and neglect in the research of health problems of agricultural product carriers who are the means of transportation in Nigeria compared to attention given to other aspect of agricultural production, which over the years have enjoyed multiple research work findings and solutions. In other words, qualitative information on health hazards of agricultural load carriers is lacking or not even available or is obsolete. Therefore considering the vital role that the agricultural product carries plays in the nation's economy, assessment of the mode of the transportation technology being used and its effect on the health condition of the agricultural product carries will reveal the extent of development in this sector. The main objective of the study was to determine the consequential 
effect of agricultural product carrying on the health of the carriers in the selected markets in Ibadan North Local Government Area of Oyo State.

\section{METHODOLOGY}

The area covered for this research is Ibadan Municipal Oyo State. The area of study is within the jurisdiction of the Ibadan municipal, which comprises of the Ibadan North, Ibadan North East, Ibadan South East, Ibadan North west and Ibadan South West. Ibadan municipal is bounded in the North by Ido Local Government Area, located between latitude $7^{\circ} 24^{\prime} \mathrm{N}$ and longitude $3^{\circ} 57^{\prime} \mathrm{E}$. The population of the area is estimated to be three hundred thousands, nine hundred and thirty nine $(300,939)$ (NPC, 1991). Major occupation of the people is trading, however some inhabitants engage in other jobs like public service (including teaching), industry (including craftsmanship and repairs). Farming is not on a very large scale in this local government area because it is in an urban center. The target population for this study is the agricultural product carriers in the markets of Ibadan Municipal that use carts, wheelbarrows, shoulder, head and other forms to convey agricultural products. Out of seven major markets in Ibadan Municipal, three markets were purposively selected because a large proportion of agricultural product carriers were found there. These markets were Bodija, Sango and Agodi gate. Simple random sampling method was used to select 40 respondents in each market. A total of 120 respondents were selected for the research project. Primary data were collected through the use of interview schedule. Descriptive statistics (frequency counts and percentages) and inferential statistics (Chi-square and Pearson Product Moment Correlation (PPMC) were used to test the objectives and hypotheses of the study.

\section{RESULTS AND DISCUSSION}

The result of the research is based on the objectives and hypotheses of the study on the activities of the agricultural products carriers commonly known as "Alaburu".

Table 1 shows that a large proportion $(51 \%)$ of the respondents are male but an appreciable
Table 1: Distribution of characteristics of respondents $\mathbf{N}=\mathbf{2 0}$

\begin{tabular}{|c|c|c|}
\hline \multirow{2}{*}{$\frac{\text { Variables }}{\text { Sex }}$} & \multicolumn{2}{|c|}{ Frequency Percen } \\
\hline & & \\
\hline Male & 61 & 51.0 \\
\hline Female & 59 & 49.0 \\
\hline \multicolumn{3}{|l|}{ Age Range } \\
\hline $16-20$ & 11 & 9.2 \\
\hline $21-25$ & 24 & 20.0 \\
\hline $26-30$ & 37 & 31.0 \\
\hline $31-35$ & 22 & 18.0 \\
\hline $36-40$ & 19 & 16.0 \\
\hline 41 and above & 7 & 58 \\
\hline \multicolumn{3}{|l|}{ Marital Status } \\
\hline Single & 47 & 39.2 \\
\hline Married & 45 & 37.5 \\
\hline Widowed & 10 & 8.3 \\
\hline Divorced & 6 & 5.0 \\
\hline Separated & 12 & 10 \\
\hline \multicolumn{3}{|l|}{ Religion } \\
\hline Christian & 59 & 49.0 \\
\hline Islam & 61 & 51.0 \\
\hline Traditional & - & - \\
\hline \multicolumn{3}{|l|}{ Educational Attainment } \\
\hline $\begin{array}{l}\text { Non formal } \\
\text { education }\end{array}$ & 49 & 41.0 \\
\hline Adult literacy & 26 & 21.0 \\
\hline $\begin{array}{l}\text { Primary } \\
\text { education }\end{array}$ & 37 & 31.0 \\
\hline $\begin{array}{l}\text { Secondary } \\
\text { education }\end{array}$ & 8 & 7.0 \\
\hline \multicolumn{3}{|l|}{ Length of Practice (years) } \\
\hline $1-5$ & 20 & 17.0 \\
\hline $6-10$ & 33 & 27.0 \\
\hline $11-15$ & 22 & 18.0 \\
\hline $\begin{array}{l}16 \text { years } \\
\text { and above }\end{array}$ & 45 & 38.0 \\
\hline \multicolumn{3}{|l|}{ Source of Income } \\
\hline Load carring & 98 & 81.7 \\
\hline Farming & 6 & 5.0 \\
\hline Trading & 9 & 7.5 \\
\hline Hawking of goods & 7 & 5.8 \\
\hline \multicolumn{3}{|l|}{ Daily Income } \\
\hline Less than or equal 50 & 3 & 2.5 \\
\hline $51-100$ & 13 & 10.8 \\
\hline $101-150$ & 22 & 18.3 \\
\hline $151-200$ & 32 & 26.3 \\
\hline 200 and above & 50 & 41.7 \\
\hline \multicolumn{3}{|l|}{ Mode of Carriage } \\
\hline Head carriage & 42 & 35.0 \\
\hline Carts carriage & 19 & 16.0 \\
\hline Wheel barrow & 32 & 27.0 \\
\hline Car carriage & 2 & 2.0 \\
\hline Shoulder & 25 & 20.0 \\
\hline \multicolumn{3}{|l|}{ Member of Cooperative } \\
\hline Yes & 77 & 64.0 \\
\hline No & 43 & \\
\hline
\end{tabular}

Source: Field Survey, 2004.

number of them (49\%) are female. This implies that both male and female are involved in the carriage of agricultural products in the selected markets. A large proportion (31\%) of the 
respondents are between ages 26-30 years old, eighteen percent of the respondents are between 31-35 years old, only seven percent are above 41 years old. About 78 percent of the respondents fall within 16-35 years of age. This implies that majority of the agricultural load carriers are young and so, very energetic to be able to face the challenges of load carrying. Large proportion $(39 \%)$ of the respondents were single while an appreciable number (38\%) were married. This implies that both single and married persons are involved in the carrying of agricultural load/ product in the selected market. Majority (51\%) of the agricultural product carriers are Muslims while an appreciable number $(49.0 \%)$ are Christian. This shows that faith base has no effect on whether or not an individual should engage in load carrying.

Majority $(62.0 \%)$ of the respondents had non-formal education. About 31 percent of the respondents had primary education. This implies that a large proportion of the respondents are literate (but with low level of education). Very few of the respondents $(7.0 \%)$ had secondary education. This contradicts the fact that these agricultural product carriers are characterized as illiterate, however, they are less privileged people or people migrating from rural areas in search of greener pastures. A large proportion of the respondents $(38 \%)$ had been on the job for over 16 years. Majority (82\%) of the respondents carry agricultural products as their main source of income. A large proportion (42\%) earn above $\aleph 200.00$ as daily income. Large proportion (35\%) of the respondents use head carriage to transport the various agricultural products to their destination. In addition, an appreciable number $(27 \%)$ uses wheelbarrow to carry the agricultural product. Majority (64\%) of the respondents are members of one cooperative society or the other while about 36 percent are not members of any cooperative society. This implies that majority of the respondents join cooperative society for networking and assistance.

The high portion of no response on Table 2, shows that majority of the respondents have load carrying as their major source of income generation. However, many of them engage in some other income generating activities to supplement with what they get from load carrying which is not enough for them to survive on, especially the married one. The aspirations of these agricultural product carriers were initially high before migrating to the urban areas. Most times, the situation was different from what they initially expected, therefore in order to survive in their new environment; they engaged themselves in a lot of activities for their survival such as carrying both agricultural and non-agricultural products. These activities include: selling snacks, probably bought from the processors to resell, tailoring, and by their kids. They are engaged in craft work, carpentry, food processing and farming. Table 2 also, shows an appreciable number $(38 \%)$ and $(35 \%)$ of the respondents indicated that domestic services and home gardening respectively are important sources of income for them.

Table 2: Distribution on secondary activities engaged in by the respondents

\begin{tabular}{|c|c|c|c|c|}
\hline Activities & $\begin{array}{l}\text { Not } \\
\text { Import- } \\
\text { ant } \\
\text { Freq- } \\
\text { uency } \\
(\%)\end{array}$ & $\begin{array}{l}\text { Import- } \\
\text { ant } \\
\text { Freq- } \\
\text { uency } \\
(\%)\end{array}$ & $\begin{array}{l}\text { Very } \\
\text { Import- } \\
\text { ant } \\
\text { Freq- } \\
\text { uency } \\
(\%)\end{array}$ & $\begin{array}{l}\text { No } \\
\text { Response } \\
\text { Freq- } \\
\text { uency } \\
(\%)\end{array}$ \\
\hline Selling snacks 1 & $13(11)$ & $13(11)$ & $9(7)$ & $35(29)$ \\
\hline Tailoring & $10(8)$ & $7(6)$ & $7(6)$ & $96(8)$ \\
\hline Home gardening & g $5(4)$ & $42(35)$ & $15(13)$ & $58(48)$ \\
\hline Domestic service & e $5(4)$ & $46(38)$ & $8(7)$ & $61(51)$ \\
\hline Child labour & $7(6)$ & $10(8)$ & $8(7)$ & $95(79)$ \\
\hline Craft work & $11(9)$ & $15(13)$ & $6(5)$ & $88(73)$ \\
\hline Carpentry & $6(5)$ & $8(7)$ & $9(8)$ & $97(81)$ \\
\hline Food processing & $5(4)$ & $18(15)$ & 11(9) & $86(72)$ \\
\hline Farming & $4(3)$ & $17(14.2)$ & $22(18)$ & $77(64)$ \\
\hline
\end{tabular}

Source: Field Survey, 2004

Table 3 shows that a large proportion (45\%) of the respondents engage in load carrying and other activities during off-planting season. Also, an appreciable number (29\%) engage in load carrying and other activities during the dry season. This shows that the agricultural season affects their engagement in load carrying and other activities. This would be because that rain disturbs them during rainy season as some will find it difficult to work at that time. It could also

Table 3: Distribution on the season that they engage in load carrying activities

\begin{tabular}{lcc}
\hline Variable & Frequency & Percentage \\
\hline Raining season & 31 & 26.0 \\
Dry season & 36 & 29.0 \\
Off-planting season & 54 & 45.0 \\
\hline Total & 120 & 100.0 \\
\hline
\end{tabular}

Source: Field survey 2004 
mean that they have to return to their respective villages to farm before coming back to the city to engage in load carrying activity.

Figure 1 reveals that majority $(65 \%)$ engaged in activity on full-time basis while 35 percent of the respondents engage in it on part time basis. This shows that load carrying is the major source of income for many of the respondents. Meanwhile, those who engage in the activity on part time basis do so, only when they are in urgent need of money or during lean period.

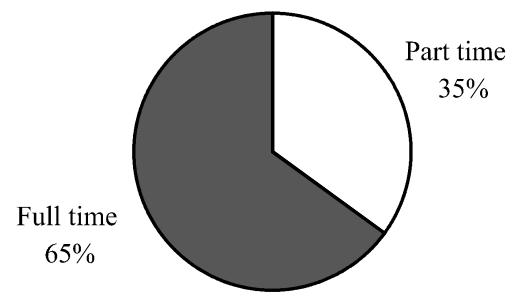

Fig. 1. Distribution of respondents on their engagement status on the activities

Anyanwu (1993), confirmed that significant proportion of Nigerians do not enjoy a level of health that will enable them to achieve socially and economically productive lives. The persistent health problems, adverse effects of the activities of the agricultural product carriers, high morbidity and mortality rates, have greatly impaired agricultural product carriers' potentials for optimum livelihood. The state of health of a person is directly related to his efficiency in his field of work, as health is important to the body

Table 4: Frequency distribution of the respondents health problems

\begin{tabular}{lrlll}
\hline $\begin{array}{l}\text { Health } \\
\text { Problems }\end{array}$ & $\begin{array}{l}\text { Rarely } \\
\text { freq- } \\
\text { uency } \\
(\%)\end{array}$ & $\begin{array}{l}\text { Occasio } \\
\text { nally } \\
\text { freq- } \\
\text { uency } \\
(\%)\end{array}$ & $\begin{array}{l}\text { Freq } \\
\text { uently } \\
\text { freq- } \\
\text { uency } \\
(\%)\end{array}$ & $\begin{array}{l}\text { Total } \\
\text { freq- } \\
\text { uency }\end{array}$ \\
\hline $\begin{array}{l}\text { Malaria } \\
\text { Body pains }\end{array}$ & $28(23)$ & $63(53)$ & $\begin{array}{l}29(24) \\
\text { Spinal cord }\end{array}$ \\
injury & $5(4)$ & $108(90)$ & $71(6)$ & $120(100)$ \\
Hynea & $16(13)$ & $90(75)$ & $14(12)$ & $120(100)$ \\
Mortality & $11(9)$ & $87(73)$ & $22(18)$ & $120(100)$ \\
Stomach pain & $26(22)$ & $57(46)$ & $37(32)$ & $120(100)$ \\
Nodules in body & $12(10)$ & $69(57)$ & $39(33)$ & $120(100)$ \\
Itching in body & $23(19)$ & $52(43)$ & $45(38)$ & $120(100)$ \\
Persistent cough & $24(20)$ & $64(53)$ & $32(27)$ & $120(100)$ \\
Guinea worm & $16(13)$ & $85(71)$ & $19(16)$ & $120(100)$ \\
\hline Source: Field & & & &
\end{tabular}

Source: Field survey 2004 and economic development. Table 4 shows that majority $(51 \%)$ of the respondents frequently have body pains, this is one of the major health implications of load carrying. While an appreciable number (28\%) frequently had body itching. This could be as a result of the fact that they sweat a lot. About 90 percent of the respondents occasionally have spinal cord injury and 75 percent occasionally have hynea. This condition is as a result of the heaviness of the load they carry both on their neck and their back. This implies that due to the nature of their job the respondents frequently experience one health problem or the other. It is very sad to note that large proportion ( $73 \%$ ) dies due to load carrying.

Table 5 shows that half of the respondents $(50.0 \%)$ occasionally seek for medical help. About 6.7 percent of the respondents seek medical help regularly while a large proportion $(43.3 \%)$ rarely seeks for medical treatment. The respondents probably seek for medical help from the traditional healers, which is very highly practiced in this area of the country. The problem of not seeking for medical assistance regularly or frequently would have resulted in high proportion of the risks in table 4. This is because, pains would have been reduced drastically and perhaps some pain tablet would have been prescribed on daily basis. The idea of not seeking for medical attention early enough could be as a result of their poverty level.

Table 5: Distribution of respondents rate of seeking for medical help

\begin{tabular}{|c|c|c|}
\hline Frequency seeking treatment & Frequency & Percent \\
\hline Regularly & 8 & 6.7 \\
\hline Occasionally & 60 & 50.0 \\
\hline Rarely & 52 & 43.3 \\
\hline Total & 120 & 100.0 \\
\hline
\end{tabular}

Source: Field Survey, 2004

Table 6 shows that about 2.5 percent were always absent from work, while 54.2 percent were occasionally hindered and 43.2 percent were rarely hindered. This implies that many of the respondents at one time or the other have been disallowed or unable to work due to their health problems. However, a large proportion continues to work even when they are sick. The large proportion of absenteeism would have been as a result of not seeking for medical assistance at all or early enough to reduce the scourge of those activities. 
Table 6: Distribution of respondents on frequency of their inability to work

\begin{tabular}{lcc}
\hline Frequency of inability to work & Frequency & Percent \\
\hline Always & 3 & 2.5 \\
Occasionally & 65 & 54.2 \\
Rarely & 52 & 43.3 \\
\hline Total & 120 & 100.0 \\
\hline
\end{tabular}

Source: Field Survey, 2004

Table 7 reveals that lack of income is the major constraint $(72 \%)$ faced by the respondents. This is why some were not able to own trolleys, lifters or cart carriers, which will make the work easier for them. About 75 percent of the respondents indicated that the nature of the work is not a constraint. Marital problems also affected large proportion $(72 \%)$ of the respondents. This could be as a result of the burden of domestic work, which might not be properly done due to the fact that they have to go to the market to carry load in order to generate income for the livelihood of the family. Most of the time the women carry their babies at their back to carry the loads. Most of them often leave their houses as early as eight in the morning to return home after seven in the evening.

Table 7: Frequency distribution of the respondent's constraints to their work

\begin{tabular}{lccc}
\hline Variables & $\begin{array}{c}\text { Not a } \\
\text { constraint } \\
\text { frequency }(\%)\end{array}$ & $\begin{array}{c}\text { Constraint } \\
\text { frequency } \\
(\%)\end{array}$ & $\begin{array}{c}\text { Total } \\
\text { frequency } \\
(\%)\end{array}$ \\
\hline $\begin{array}{l}\text { Terrible nature of } \\
\text { the job(health risk) }\end{array}$ & $90(75.0)$ & $30(25.0)$ & $120(100)$ \\
$\begin{array}{l}\text { Lack of Income } \\
\text { Marital constraints }\end{array}$ & $33(28.0)$ & $87(72.0)$ & $120(100)$ \\
\hline Source: Field survey 2004 & $86(72.0)$ & $120(100)$ \\
\hline
\end{tabular}

The result of the tested hypothesis on table 8 shows that there is significant association between sex $\left(\chi^{2}=1.118, \mathrm{p}<0.05\right)$, age $\left(\chi^{2}=12.911\right.$, $\mathrm{p}<0.05)$, marital status $\left(\chi^{2}=10.740, \mathrm{p}<0.05\right)$, educational background $\left(\chi^{2}=12.030 ; p=0.040\right)$ and their activities. This indicates that age, educational background and sex of the respondents affect their activity. This shows that there is age difference, which is considered in whether or not an individual should undertake such an activity. However, any sex can participate in the activity. Education is significant, which means that it is only the less educated people that engage in load carrying activity. However, this analysis also reveals that there is no significant association between faith base and their activities. It does not matter whether or not the respondent is a Christian or a Muslim or traditional worshiper, any individual from any faith base can undertake this activity.

Table 8: Significant association between the respondents selected characteristics and their activities.

\begin{tabular}{|c|c|c|c|c|}
\hline Variables & $\chi^{2}$ & $d f$ & $P$ & Remarks \\
\hline Sex and activities & 4.118 & 2 & 0. & $\mathrm{Si}$ \\
\hline Age and activities & 12.911 & 6 & 0.0 & ficant \\
\hline $\begin{array}{l}\text { Marital status and } \\
\text { activities }\end{array}$ & 10.740 & 5 & 0.040 & ficant \\
\hline Religion and activit & 4.001 & 3 & 92 & $\begin{array}{l}\text { Not } \\
\text { signifi }\end{array}$ \\
\hline Education and activities & 12.030 & 8 & 0.040 & Significant \\
\hline
\end{tabular}

Table 9 shows that there is this significant correlation between constraints faced by the agricultural product carriers and their perceived health problems $(r=0.736 ; p=0.000)$. The constraint of not having money could cause some psychological health problems. It could lead to headache, depression. These constraints have great health implications. There is also significant correlation between the activity of the respondent and their health problems $(r=0.005$; $\mathrm{p}=0.034)$. This implies that the problem in their health status is caused by all kinds of constraints that they faced. Also the load carrying activity itself poses some health problem to them.

Table 9: Significant correlation between constraints to their work, activity and their health problems

\begin{tabular}{llll}
\hline Variable & $r$ & $P$ & Remark \\
\hline Constraints & 0.736 & 0.000 & Significant \\
Activity & 0.005 & 0.034 & Significant \\
\hline
\end{tabular}

\section{CONCLUSION}

This research has shown that respondents' health problems are associated with agricultural product carrying. This is referred to as occupational health hazard that exposes the labourer to great risk. The result revealed that both men and women are engaged in product carrying. They are involved in this type of activities to meet their own needs and that of the family members. However, some constraints were identified as militating against their performance in the activity. The mode of carrying these loads has great impact on their health status. Therefore there should be an improved method of carrying loads in the markets to help this carriers especially 
women who have to back their babies while carrying loads from the drudgery of load carrying. Cooperative associations should be encouraged as they are liable agents of obtaining facilities/ assistance. Government should provide wheelbarrows, cart carriers and other easy facilities on hire purchase or at subsidized rate for them.

\section{REFERENCES}

Airey, Tony and Barwell, Ian: Village Level Transport and Travel Survey and Related Cases. Report on IT Transport Project, Sub-Saharan Africa Policy Programm. International Labour Organization Switzerland, P. 146 (1991).

Anyanwu, C.N.: The human common wealth for a humane society. Inaugural lecture. Department of Adult Education, University of Ibadan Pp. 5-20 (1993).

Bamberger, Micheal and Lebo, Jerry: Sub-Sahara African transport policy program. Working paper No 56. 2-5 (1999).

Barwell, Ian and Malmberg Calvo, C: Market Integrated Rural Transport Project: The Transport Demands of Rutral Households. Employment and Development Department. ILO. Genever, Switzerland, Pp. 25-100 (1989).

Dawson, Jonathan and Barwell, Ian: Roads are not
Enough: New Perspectives Rural Transport Planning in developing countries. Intermediate Technology Publications. London UK. Pp. 20-30 (1993)

Fasola, Mauro: Health Problems of Agricultural Product Carriers in Selected Markets of Ibadan North Local Government Area of Oyo State. B.Sc. project submitted in the department of Agricultural Extension and Rural Development. University of Ibadan Pp. 6-57 (2005).

Howe, J. and Zille, P: The Transport Demands of SmallFarm Houses in Africa: A Synthesis of IT Transport Research. IT Transport Limited Arlington UK Pp. 25-36 (1988).

International Labour Organisation Occupational Health and Safety. ILO, Geneva (1997).

National Population Commission (NPC): Nigerian Census Figure. Nigeria Pp. 1-20 (1991).

National Safety Council: Alliance Annual Report Occupational Safety and Health Administration and the National Safety Council (NSC) USA October 25 (2004).

World Bank: The World Bank and Economic Commission for Africa. Working paper No. 56 Pp. 1-5, World Bank, Washington D. C. (1999).

World Health Organization: Summary Measures of Population Health: Concepts, Ethics, Measurement and Application. Pp. 50-200 WHO, Geneva (2002). 